\title{
Mathematics Communication Skill Analysis in Means-End-Analysis Learning Assisted with Manipulative Property (APM) and Application Based on Self-Efficacy
}

\author{
Aulia Kuntum Arfani ${ }^{1}$, Isti Hidayah ${ }^{2}$, Dwijanto ${ }^{3}$ \\ ${ }^{1}$ Master Program Student of Primary Education, ${ }^{2}$ Master Program of Mathematics and Natural Sciences, ${ }^{3}$ Master \\ Program of Mathematics and Natural Sciences, Universitas Negeri Semarang, Semarang City, Indonesia \\ Corresponding Author: Aulia Kuntum Arfani
}

DOI: https://doi.org/10.52403/ijrr.20220120

\begin{abstract}
This research analyzed mathematics communication skills with the Means-End Analysis model assisted with Manipulative Property (APM), MEA with Linear System Pro application, and PBL based on the eighth graders' self-efficacy. This quasi-experimental research used a nonequivalent pretest-posttest control group design. The subjects were eighthgraders of Public JHS 4 Adiwerna. The samples were VIII-C learners as the first experimental group, VIII-G learners as the second experimental group, and VIII-H learners as the control group. The data collecting techniques were mathematics communication skill test and self-efficacy inventory. The results were: (1) MEA with APM (82.75\%), MEA with Linear System Pro (78.12\%), and PBL (75\%) of the learners reached the minimum mastery standard with a proportion percentage, $75 \%$; (2) there were mean differences between MEA assisted by APM, MEA assisted by Linear System Pro, and PBL toward the learners' mathematics communication skills, (3) there were significant differences of self-efficacy: high, moderate, and low toward the learners' mathematics communication skills; and (4) there were interactions between learning models with the levels of self-efficacy toward learners' mathematics communication skills.
\end{abstract}

Keywords: Mathematics Communication Skill, Means-End-Analysis Learning Model (MEA),
Manipulative Property (APM), Linear System Pro, Self-efficacy

\section{INTRODUCTION}

Education is an influential and crucial developmental element of a nation. Human resources will be more qualified and have better skills with an adequate education. Along with the development of the current era, humans - as social creatures - must communicate with each other in their lives.

Mathematics is a thinking mean and communication mode among learners, learners-teachers, and teachers-learners. NTCM (2000) explains that the objective of mathematics lessons is to teach how to communicate. Mathematics communication skills are important in a mathematics lesson. Mathematics communication skill deals with the concept of recognition and the inter-idea correlation and abstract language with mathematics symbols. They include speaking, writing, and drawing table, and graphic skills (Astuti \& Leonard, 2012). Mathematics communication skill in this research refers to learners' skills to state and illustrate mathematics ideas to be mathematics model and vice versa. The objective of the mathematics lesson, based on the 2013 curriculum, is to emphasize the pedagogic aspect via a scientific approach (Kemendikbud, 2013). Rusnan (2015) 
develops scientific stages into eight stages. They observe, ask, reason, try, process, present, conclude, and communicate. Sholihah et al. (2017) found that learners had difficulties communicating the written questions about the flat sides of geometry into a figure and vice versa.

Based on the interview with mathematics teachers of random JHS in Tegal, the researchers found poor mathematics communication skills of the learners. They could not interpret the question items and obtain answers. Excellent mathematics communication skills facilitate learners to elaborate mathematics ideas. Thus, they need correct strategies with appropriate learning models. A learning model that could improve mathematics communication skills is Mean End Analysis or MEA (Juanda et al., 2014).

MEA is a learning variety to solve problems. It aims to create detailed results (Shoinim, 2014). Learning with MEA develops problem-solving type learning syntaxes with a heuristic approach. The learning also includes sub-elaborative problems in a modest form, dissimilarity identification, sub-problem arrangement to create a certain connection, and accurate solution creation (Suherman cited in Juhrani et al., 2017). Teachers should create a learning process atmosphere with adequate opportunities for learners to actively participate, seek, process, construct, and use their knowledge. Thus, they could reach the objective of the learning. Heruman (2013) explains that abstract mathematics learning makes learners need assistance. For example, learning media could clarify and elaborate the delivered explanation. Thus, learners could understand and know the material. One of the applicable media by teachers is manipulative property (APM). Manipulative property in learning mathematics refers to applicable learning tools to explain mathematics concepts and procedures. Thus, learners will understand the learning materials easily. Ristanti (2016) found that using manipulative property in integrative-thematic learning of primary school could improve motivation and skills. The use of the property could facilitate the mathematics material delivery. Thus, learners could understand the mathematics concepts, learn effectively, and improve their learning outcomes (Rizki et al., 2017). With the development of information and communication technology, learning media also develops quickly. One of them is a gadget. Ernest Doku, a telecommunication expert of Uswitch.com, explains - approximately twenty million children have tables before their eight years old. They also can use their tablets to find information, entertainment, and social relationship (Murdaningsih\& Faqih, 2014). At the present day, digital-based learning media develops quickly. One of them is an android-based phone. Learners have many various supportive applications to learn mathematics. One of them is Linear System Pro. This application contains SPLDV or a two-variable linear equation system to solve mathematics questions. Learners can download this application via Playstore. Kartika (2014) found that Matlab software for learners could improve their mathematics communication skills and learning interest.

According to the Ministerial Regulation of Ministry of Education and Culture Number 103, the Year 2014, 2013 curriculum emphasizes three primary learning models. They are discovery learning, project-based learning, and problem-based learning. The government expects the model could build learners' scientific, social, and curious behaviors. In this research, the researchers took Problembased learning for the control group. The researchers took three classes as the sample groups of this research. The first group, the first experimental group, received MEA learning with APM. The second experimental group received MEA with Linear System Pro. Then, the control group received problem-based learning.

Problems related to low learning outcomes dealt with learners' self-efficacy to solve problems. An individual's self- 
efficacy refers to his or her belief to manage and execute the required action program. Thus, the individual could realize his or her self-efficacy (Bandura, 1997). Hamdi \& Abadi (2014) explains that self-efficacy influences an individual's learning achievement. Higher self-efficacy leads to higher readiness to engage with a certain situation. Thus, the individual could create a positive matter. Self-efficacy also refers to learners' judgment skills toward their tasks and effort to solve difficulties (Putri \&Santosa, 2015).

From the background, the investigated problem was the potency of MEA learning with APM, MEA learning assisted by Linear System Pro, and PBL model to improve mathematics communication skills of learners based on their self-efficacy.

This research aims to determine the proportion of learners' mathematics communication skills on the three models that could reach a percentage of $75 \%$. The research also determined which learning model was better to improve learners' mathematics communication skills based on self-efficacy.

\section{METHOD}

This quantitative research used a quasi-experimental design. Budiono (2003) explains that quasi-experimental research aims to obtain information from a real experiment in an uncontrolled situation. It means the researchers cannot manipulate all relevant variables nor keep the intervening factors while experimenting. The researcher used a nonequivalent pretest-posttest control group design with two experimental groups and one control group. The first experimental group received the MEA learning model assisted with APM. The second experimental group received an MEA learning model with a Linear System Pro application. Then, the last group, the control group, received the PBL model. Each group consisted of learners with high, moderate, and poor self-efficacy categories. This research used a 3x3 factorial design.
The researchers researched Public JHS 4 Adiwerna, Tegal regency. The subjects were eighth-graders of Public JHS 4 Adiwerna. The researchers took the three groups with cluster random sampling technique. The first experimental group consisted of 32 learners from VIII-C. Then, the second experimental group consisted of 29 learners from VIII-H. The control group consisted of 32 learners from VIII-A. The researchers used a pilot group from VIII-E, consisting of 32 learners in this research.

The data collecting techniques were test and non-test. The researchers promoted the test during the learning process. They collected the learners' mathematics communication skill test and the results of the self-efficacy inventory. On the other hand, the non-test instrument took form into observation and documentation. The researchers analyzed the data from the prerequisite test and hypothesis test. The prerequisite test consisted of normality, homogeneity, and similarity tests. Then, the hypothesis test dealt with the minimum proportional completion test and the twoway ANOVA test.

\section{RESULT AND DISCUSSION}

In this stage, the researchers measured quantitatively by providing the initial data of the learners based on the initial test. The test dealt with a two-variable linear equation system, SPLSV. The researchers used the initial knowledge test to determine the minimum mastery standard score for the learning completion. The results from three classes, consisting of 93 learners, obtained the average cognitive score of 62.44 with the lowest score, 40, and higher, 87. The researchers determined the minimum mastery standard score of mathematics communication skills from the initial data. The score was 68 . Then, the researchers provided a mathematics communication pretest for the first and second experimental groups and the control group. 
The Prerequisite Test of Mathematics Communication Skill

Normality, Homogeneity, and Mean

Similarity Tests

The prerequisite tests showed that the learners' mathematics communication skills from three groups had normal distributions. The $D_{\text {litung }}<D_{\text {tabel }}$ of the first experimental group was $0.135<0.253$; the second experimental was $0.130<0.240$; and control group was $0.188<0.240$. The pretest used the Bartlet test, showing that all groups were homogeneous with $x_{\text {count }}^{2}<x_{\text {count }}^{2}=4,606<5,99$. The mean similarity test obtained a significant score, $0.559>0.05$. Thus, the result accepted $\mathrm{H}_{0}$. It meant all groups had similar skills. The researchers also conducted a final data analysis from the posttest of learners' mathematics communication skills. The calculation stages were similar to normality and homogeneity tests. The prerequisite tests showed that the learners' mathematics communication skills from three groups had normal distributions. The $D_{\text {count }}<D_{\text {table }}$ of the first experimental group was $0.116<$ 0.253 ; the second experimental was $0.143<$ 0.240 ; and control group was $0.079<0.240$. The researchers used Bartlett as a homogeneity test of posttest results. They found that the learners' mathematics communication skills from three groups were homogeneous with $x_{\text {count }}^{2}<x_{\text {count }}^{2}=$ $2,455<5,99$.

Figure 4.1 shows the increased average scores of experimental and control groups based on pretest and posttest results.

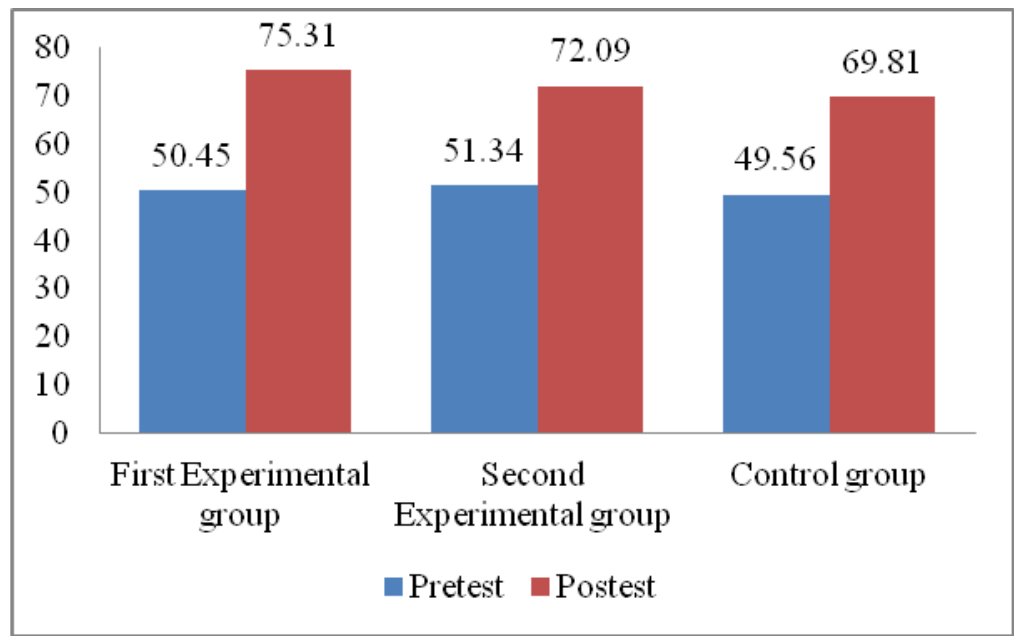

Hypothesis Test

\section{Proportional Test}

Proportional test with z-test. The calculation shows that all groups reach a proportional percentage of $75 \%$ from all learners that met the minimum mastery standard of mathematics communication skills. The highest one was MEA assisted with APM, then MEA assisted by Linear System Pro and PBL model. Table 1 explains the calculations.

Table 1. Proportional Test Result

\begin{tabular}{|l|l|l|}
\hline \multicolumn{3}{|c|}{ Table 1. Proportional Test Result } \\
\hline MEA APM & $\boldsymbol{Z}_{\text {Bitung }}$ & $-\boldsymbol{Z}_{\text {tabel }}$ \\
\hline MEA with LSP Application & 0,965 & -1.645 \\
\hline PBL & 0.408 & -1.645 \\
\hline
\end{tabular}

All groups

obtained $z_{\text {count }}>-z_{\text {table }}$ with different totals from the calculation. The results revealed the completion proportions of the first experimental group taught by MEA with APM, the second experimental group taught by MEA with Linear System Pro application, and control taught by PBL reached a percentage of $75 \%$. MEA learning model provided learners the opportunity to construct their knowledge autonomously. The model also motivated the learners to learn actively and creatively (Juhrani, Suyitno \& Khumaedi, 2017). Kania (2018) revealed that the manipulative property positively influenced material concept 
understanding and made mathematics lessons joyful. The same matter also occurred in an android-based application for training learners' learning autonomy outside of schools. An android-based application could improve learners' interest in learning mathematics. Thus, it influenced learners' learning outcomes (Batubara, 2017). In PBL learning or the control group, the proportion reached the required completion, but it was not higher than MEA assisted by APM and MEA assisted by Linear System Pro application. In the PBL group, the learners were not eager to solve the problems. Thus, the teacher motivated and guided the learners. Miranti, Agoestanto\&Kurniasih (2015) also found that PBL made teachers help the learners. Thus, the learners did not do the problem autonomously; moreover, they organized the research and presented their works. These situations made the learners have the low problem-solving eagerness. Habibah (2016) also found that mathematics problem-solving skills of learners taught by MEA were better than those with PBL.

\section{Two Way ANOVA Test}

Two Way ANOVA Test with SPSS

Figure 2 shows the test results.

\begin{tabular}{|c|c|c|c|c|c|}
\hline \multicolumn{6}{|l|}{ Dependent Variable: MMSL } \\
\hline Source & Type III Sum of Squares & Df & Mean Square & $\mathbf{F}$ & Sig. \\
\hline Corrected Model & $1163,794^{\mathrm{a}}$ & 8 & 145.474 & 5.004 &, 000 \\
\hline Intercept & 339490.522 & 1 & 339490.522 & 11677.029 &, 000 \\
\hline LEARNING-MODEL & 239.048 & 2 & 119.524 & 4.111 & 020 \\
\hline SELF_EFFICACY & 398.834 & 2 & 199.417 & 6.859 & ,002 \\
\hline LEARNING_MODEL*SELF_EFFICACY & 320.573 & 4 & 80.143 & 2.757 & 033 \\
\hline Error & 2442.163 & 84 & 29.073 & & \\
\hline Total & 489903.000 & 93 & & & \\
\hline Corrected Total & 3605.957 & 92 & & & \\
\hline
\end{tabular}

Table 2 consists of 3 lines representing the research hypothesis test results.

\section{The Differences among Learning Models toward Mathematics Communication Skills}

The calculation obtained significant scores to determine different mean scores of the learning models toward mathematics communication skills, $0.020<0.05$. Thus, the score shows a mean difference of MEA assisted by APM, MEA assisted by LSP, and PBL toward mathematics communication skills.

\section{The Differences among Self-Efficacy Categories and Mathematics Communication Skills}

The calculation obtained significant scores to determine different mean scores of self-efficacy categories: high, moderate, and poor, toward mathematics communication skills, $0.002<0.05$. Thus, the score shows a mean difference of high, moderate, and poor self-efficacy categories toward mathematics communication skills.

\section{The Interaction of Learning Models and Self-Efficacy toward Mathematics Communication Skills}

The researchers used the obtained significant scores to determine the interaction of learning models and selfefficacy models from the calculation. The score is $0.033<0.05$. The researchers found an interaction between learning models and self-efficacy toward mathematics communication skills from the score.

The hypothesis test with two-way ANOVA test found all hypotheses had differences among the variables. The differences were observable from the significant differences via post-hoc test by LSD test. Here are the explanations:

\section{Learning Model}

The significant differences between the three learning models are based on posthoc tests. 
Aulia Kuntum Arfani et.al. Mathematics communication skill analysis in means-end-analysis learning assisted with manipulative property (APM) and application based on self-efficacy.

Table 4 the Post-Hoc Test of the Learning Models

\begin{tabular}{|c|c|c|c|c|c|c|}
\hline \multirow[t]{2}{*}{ Learning Model } & \multirow{2}{*}{ Learning Model } & \multirow[t]{2}{*}{ Mean Difference } & \multirow[t]{2}{*}{ Std. Error } & \multirow[t]{2}{*}{ Sig. } & \multicolumn{2}{|c|}{ 95\% Confidence Interval } \\
\hline & & & & & Lower Bound & Upper Bound \\
\hline \multirow{2}{*}{ MEA APM } & MEA LSP Application & $.3 .22 *$ & 1.382 & ,022 & ,47 & 5.97 \\
\hline & PBL & $5,50 *$ & 1.382 &, 000 & 2.75 & 8.25 \\
\hline \multirow{2}{*}{ MEA with LSP Application } & MEA APM & $-3,22 *$ & 1.382 & ,022 & -5.97 &,- 47 \\
\hline & PBL & 2.28 & 1.348 & ,094 &,- 40 & 4.96 \\
\hline \multirow[t]{2}{*}{ PBL } & MEA with LSP Application & -2.28 & 1.348 & ,094 & -4.96 & 40 \\
\hline & MEA APM & $-5,50 *$ & 1.382 &, 000 & -8.25 & -2.75 \\
\hline
\end{tabular}

Based on observed means.

The error term is Mean Square (Error) $=29,073$

*The mean difference is significant at the 0,05 level.

Table 4 shows the post-hoc test of LSD. The mean of learners' mathematics communication skills taught by MEA assisted by APM is higher than learners taught by MEA assisted by LSP. The result is observable from the mean difference of post-hoc test of the two models, 3.22. On the other hand, the learners' mathematics mean score of learners taught by MEA assisted with LSP is insignificant. The result is similar with learners taught by PBL with a mean difference of post-hoc test, 2.28. The role of mathematics communication skills in the MEA model was important. The model made learners cooperate in groups to find the problem-solution. Then, they delivered the results in front of the class to collect responses from other groups (Putri et al., 2017). Sidiq\& Kania (2018) also found that learners' activities taught by APM could improve their learning achievements and masteries. Thus, their mathematics learning outcome averages on each cycle could improve. Hidayah et al. (2018) stated that integrated manipulative property in mathematics lessons could improve learners' conceptual understanding. Learners had positive and active responses. They also cooperated to solve the worksheet assisted with APM SLPDV, manipulative property of two-variable linear equation system. Hidayah et al. (2018) also found that learners positively responded to individual APM so they could actively participate and think.

\section{b. Self-efficacy}

The researchers determined the differences of learners' self-efficacy categories toward mathematics communication skills based on post-hoc test table.

\begin{tabular}{|c|c|c|c|c|c|c|}
\hline \multicolumn{7}{|c|}{$\begin{array}{c}\text { Table 5. Advanced Self-Efficacy Test } \\
\text { Multiple Comparisons } \\
\text { Dependent Variable: MMSL } \\
\text { LSM } \\
\end{array}$} \\
\hline \multirow{2}{*}{ SELF_EFFICACY } & \multirow{2}{*}{ SELF_EFFICACY } & \multirow{2}{*}{ Mean Difference } & \multirow{2}{*}{ Std. Error } & \multirow[t]{2}{*}{ Sig. } & \multicolumn{2}{|c|}{ 95\% Confidence Interval } \\
\hline & & & & & Lower Bound & Upper Bound \\
\hline \multirow[t]{2}{*}{ HIGH } & MODERATE & $.4 .57 *$ & 1.660 & 007 & 1.26 & 7.87 \\
\hline & POOR & $.7 .21 *$ & 1.857 &, 000 & 3.52 & 10.91 \\
\hline \multirow[t]{2}{*}{ MODERATE } & HIGH & $-4,57 *$ & 1.660 & 007 & -7.87 & -1.26 \\
\hline & POOR & $2,65^{*}$ & 1.316 & 0.47 & ,03 & 5.26 \\
\hline \multirow[t]{2}{*}{ POOR } & HIGH & $-7,21 *$ & 1.857 &, 000 & -10.91 & -3.52 \\
\hline & MODERATE & $-2,65 *$ & 1.316 & ,047 & -5.26 &,- 03 \\
\hline
\end{tabular}

Table 5 shows the post-hoc LSD test result of the inter-group differences.

1) High self-efficacy and moderate selfefficacy categories have as significant difference, $\alpha=0,007<0,05$.

2) High self-efficacy and poor self-efficacy categories have as significant difference, $\alpha=0,000<0,05$.
3) High self-efficacy and poor self-efficacy categories have as significant difference, $\alpha=0,007<0,05$.

Self-efficacy makes individuals differ in actions as the follow-up of the feeling and cognition. Thus, the differences influence the learners' confidence. Rahmi et al. (2017) found that self-efficacy was 
Aulia Kuntum Arfani et.al. Mathematics communication skill analysis in means-end-analysis learning assisted with manipulative property (APM) and application based on self-efficacy.

influential in learners' mathematics communication skills. The high selfefficacy learner category in mathematics skills would have higher mathematics communication skills and vice versa.
Susanti (2018) also found that high selfefficacy learners had better academic achievements than learners with poor selfefficacy.

\section{c. The Interaction of Learning Model and Self-Efficacy}

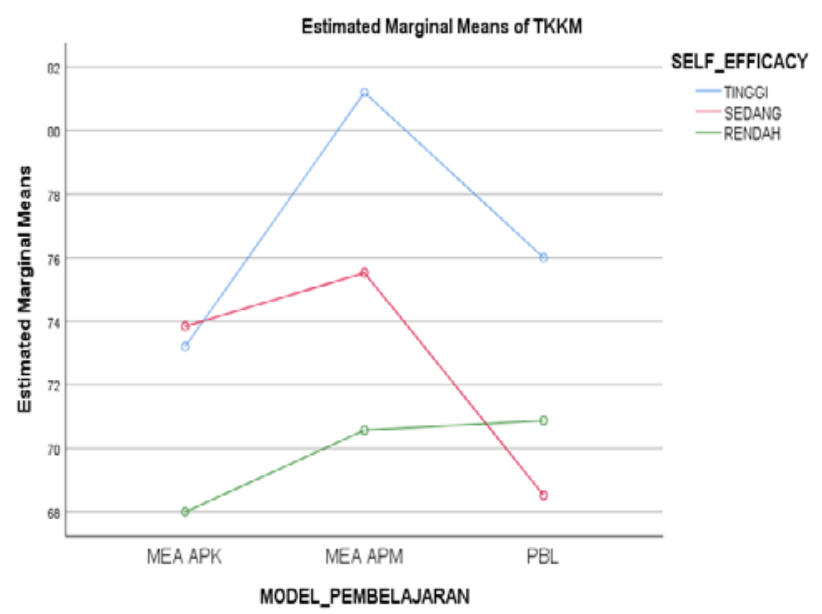

From the graphics, the lines are not parallel. This matter indicates interaction between the learning model and selfefficacy toward mathematics communication skills.

\begin{tabular}{|l|l|l|}
\hline Learning Model & Self-efficacy & Average \\
\hline \multirow{4}{*}{ MEA APM } & High & 81.20 \\
\cline { 2 - 3 } & Moderate & 75.53 \\
\cline { 2 - 3 } & Poor & 70.57 \\
\hline \multirow{5}{*}{ MEA with LSP Application } & High & 73.20 \\
\cline { 2 - 3 } & Moderate & 73.83 \\
\cline { 2 - 3 } & Poor & 68.00 \\
\hline \multirow{3}{*}{ PBL } & High & 76.00 \\
\cline { 2 - 3 } & Moderate & 68.52 \\
\cline { 2 - 3 } & Poor & 70.88 \\
\hline
\end{tabular}

From the post-hoc test, the researchers found the interaction between the learning model and self-efficacy toward mathematics communication skills. Learners taught by MEA with APM had high selfefficacy. Thus, their mathematics communication skill average score was higher than those taught by MEA with LSP application. The high self-efficacy learner categories obtained 81 for MEA with APM group and 73 for MEA with LSP application group. On the other hand, learners taught by PBL with the high self-efficacy category had better mathematics communication skills than those taught by MEA assisted with LSP application. The high self-efficacy learners with the PBL model obtained a score of 76, while learners with MEA assisted with LSP application obtained a score of 73. Juhrani et al. (2018) revealed that high self-efficacy learners could reveal written mathematics ideas in mathematics communication. Thus, they could find the solution to the given problems although they made minor mistakes and lack of carefulness. Moderate self-efficacy learners taught by MEA with APM had higher mathematics communication skill average scores than those taught by MEA with LSP application. The moderate self-efficacy learner categories obtained 76 for MEA with APM group and 74 for MEA with LSP application group.

On the other hand, learners taught by PBL with moderate self-efficacy had better mathematics communication skills than those taught by MEA assisted with LSP application. The moderate self-efficacy learners with the PBL model obtained a score of 74, while learners with MEA assisted with LSP application obtained a score of 69. Poor self-efficacy learners 
taught by MEA with APM had lower mathematics communication skill average scores than those taught by MEA with LSP application. The poor self-efficacy learner categories obtained 68 for MEA with APM group and 71for MEA with LSP application group. On the other hand, learners taught by PBL with poor self-efficacy had better mathematics communication skills than those taught by MEA assisted with LSP application. The poor self-efficacy learners with the PBL model obtained a score of 68 while learners with MEA assisted with LSP application obtained 71. Poor self-efficacy learners had difficulties expressing their mathematics ideas. Thus, the obtained solutions were incorrect (Juhrani et al., 2018). The researchers found learners taught by MEA assisted with LSP application were active in finding solutions to the problems. They had the motivation to check the truth of the answers with the Linear System Pro application. They did it, starting with the substitution method, elimination, and graphic drawing. However, some learners still had problems using android, although the teachers had guided them. Umbara \& Rahmawati (2018) found that softwarebased learning activity could promote smooth learning, although the users might find difficulties at the beginning. It happened due to different mechanisms that required habitual adaptation.

\section{CONCLUSION}

From the result and discussion, the learners' mathematics communication skills improved while receiving MEA assisted by APM, MEA assisted by Linear System Pro, and PBL with a proportional completion of $75 \%$. However, the highest one was found in MEA assisted by APM. The learners' mathematics communication skills from three groups could reach the applied minimum standard mastery score. Learners from MEA with APM group achieved a percentage of $83 \%$, MEA with Linear System Pro achieved a percentage of $78 \%$, and PBL model group reached $75 \%$. The mean End Analysis learning model could improve learners' mathematics communication skills. Learning media with manipulative property and android-based applications, such as Linear System Pro, positively influenced learners' mathematics communication skills. The posttest results of the learners were better than their pretest results. However, their practices still had some difficulties. MEA learning model with APM, MEA learning model with Linear System Pro, and PBL model could create high, moderate, and low self-efficacy interactions toward learners' mathematics communication skills. High self-efficacy learners that received MEA learning model with APM, MEA learning model with Linear System Pro, and PBL had higher and better mathematics communication skills than those with moderate or poor selfefficacy categories.

\section{Acknowledgement: None}

\section{Conflict of Interest: None}

\section{Source of Funding: None}

\section{REFERENCES}

1. Astuti, A. dan Leonard. 2015. Peran Kemampuan Komunikasi Matematika Terhadap Prestasi Belajar Matematika Siswa. JurnalFormatif, 2(2): 102-110. Retrieved from https://journal.lppmunindra.ac.id/index.php/ Formatif/article/view/91

2. Bandura, A. 1997. Self-Efficacy: The Exercise of Control. New York: W.H Freeman and Company

3. Batubara, H, H. 2017. Pengembangan Media Pembelajaran Matematikaberbasis Android untukSswa SD/MI. MUALLIMUNA: Jurnal Madrasah Ibtidaiyah. 3(1): 12-27. Retrieved from https://ojs.uniska-

bjm.ac.id/index.php/jurnalmuallimuna/articl e/view/952

4. Budiono. 2003. MetodologiPenelitian Pendidikan. Surakarta: UNS Press.

5. Habibah, U. 2016. Eksperimen Model PBL dan MEA TerhadapKemampuan Pemecahan Masalah Siswa Kelas VII SMP N 6 Purworejo. EKUIVALEN: Jurnal 
Aulia Kuntum Arfani et.al. Mathematics communication skill analysis in means-end-analysis learning assisted with manipulative property (APM) and application based on self-efficacy.

Pendidikan Matematika. 23(1): 20-26. Retrieved from http://ejournal.umpwr.ac.id/index.php/ekuiv alen/article/view/3151

6. Hamdi, S., Abadi, A.M. 2014. PengaruhMotivasi, Self Efficacy dan Latar Belakang Pendidikan Terhadap Prestasi MatematikaMahasiswa PGSD STKIP-H dan PGMI IAIH. JurnalRiset Pendidikan Matematika. 1(1): 77-87. Retrieved from https://journal.uny.ac.id/index.php/jrpm/arti cle/view/2666

7. Heruman. 2013. Model Pembelajaran Matematika di Sekolah Dasar Bandung: PT RemajaRosdakarya.

8. Hidayah, I., Dwijanto., Istiandaru, A. 2018. , Manipulatives and Question Series for Elementary School Mathematics Teaching on Solid Geometry 11(3): 650-662. Retrieved from https://eric.ed.gov/?id=EJ1183443

9. Juanda, M, R., Johar, M, I. 2014. Peningkatan Kemampuan Pemecahan Masalah dan KomunikasiMatematisSiswa SMP Melalui Model Means-ends Analysis. Kreano. 5(2) : 105-113. Retrieved from https://journal.unnes.ac.id/nju/index.php/kre ano/article/view/3322

10. Juhrani., Suyitno, H., Khumaedi. 2018. AnalisisKemampuanKomunikasiMatematis Berdasarkan Self Efficacy Siswa pada Model Pembelajaran MEA. Unnes Journal of Mathematics Education Research. 6(2): 251-258. Retrieved from https://journal.unnes.ac.id/sju/index.php/ujm er/article/view/20604/9779

11. Kania, N. $2018 . \quad$ Alat PeragauntukMemahamiKonsepPecahan. Jurnal Theorems. 2(2): 1-12. Retrieved from http://jurnal.unma.ac.id/index.php/th/article/ view/699

12. Kartika, H. 2014.Pembelajaran Matematika Berbantuan Software MatlabSebagai UpayaMeningkatkanKemampuanKomunika siMatematis dan MinatBelajarSiswa SMA. Jurnal Pendidikan Unsika. 2(1): 24-35. Retrieved from https://journal.unsika.ac.id/index.php/judika /article/view/119

13. Kemendikbud. 2013. Kerangka Dasar dan StrukturKurikulum 2013. Jakarta: Kemendikbud.

14. Miranti, N.K., Agoestanto, A., Kurniasih, A.W. 2015. KomparasiPembelajaran MEA dan PBL TerhadapKemampuan Pemecahan
Masalah dan DisposisiMatematisSiswa SMP Kelas VIII Pada Materi SPLDV. Unnes Journal of Mathematics Eeducation. 4(3): 213-221.Retrieved from https://journal.unnes.ac.id/sju/index.php/ujm e/article/view/9061

15. Murdaningsih, D., Faqih, M. 2014. Survei: Jutaan Anak Usia SD Kecanduan Gadget. Retrieved from https://www.republika.co.id/berita/trendtek/ gadget/14/01/17/mzjj2x-survei-jutaan-anakusia-sd-kecanduan-gadget (diaksestanggal 20 Februari 2020)

16. NCTM, 2000. Principles and Standards for School Mathematics. Reston: NCTM.

17. Putri, E.F., Buchori, A., Shodiqin, A. 2017. EfektivitasPembelajaranMatematikaMenggu nakan Model Course Review Horay dan Means Ends Analysis Berbantu Algebrator TerhadapKemampuanKomunikasiMatemati sSiswa SMP. Prosiding Seminar Nasional Matematika dan Pendidikan Matematika (2nd Senatik) Universitas PGRI Semarang. (pp 269-277). Retrieved from http://prosiding.upgris.ac.id/index.php/sen_ 2017/sen_2017/paper/view/1661

18. Putri, R.I., Santosa, R.H. 2015. Keefektifan Strategi REACT ditinjaudariPrestasiBelajar, KemampuanPenyelesaianMasalah, Koneksi Matematis, Self Efficacy. JurnalRiset Pendidikan Matematika. 2(2): 262-272. Retrieved from https://journal.uny.ac.id/index.php/jrpm/arti cle/view/7345

19. Rahmi, S., dkk. 2017. The Relation Between Self-Efficacy Toward Math with The Math Communication Competence. Journal of Mathematics Education. 6(2): 177-182. Retrieved from http://ejournal.stkipsiliwangi.ac.id/index.php/infinit y/article/view/349

20. Ristanti, Y. 2016. PeningkatanMotivasi dan KeterampilanHitungPecahanDesimalMelalu i Media Manipulatif Pada Pembelajaran Tematik-Integratif SD. JurnalRiset Pendidikan Matematika. 3(1): 122-136. Retrieved from https://journal.uny.ac.id/index.php/jrpm/arti cle/view/9686

21. Rizki, L. D, Yensy B. N. A, Rusdi. 2017. Perbandingan Hasil Belajar Antara PembelajarandenganMenggunakan Media ManipulatifdenganPembelajaranKonvension al. JP2MS. 1(1) : 47-53. Retrieved from 
Aulia Kuntum Arfani et.al. Mathematics communication skill analysis in means-end-analysis learning assisted with manipulative property (APM) and application based on self-efficacy.

https://ejournal.unib.ac.id/index.php/JPPMS /article/view/2589

22. Rusman. 2015. Pembelajaran Tematik TerpaduTeoriPraktik dan Penilaian. Jakarta: Rajawali Pers.

23. Shoimin, A. 2014. 68 Model PembelajaranInovatifdalamKurikulum 2013. Yogyakarta: Ar-Ruz Media.

24. Sholihah, M., et all. 2017. Keefektifan Model Pembelajaran Three Sep Interview BerbasisScientifikterhadapKemampuankom unikasiMatematisSiswa Kelas VIII MateriBangun Ruang Sisi. Prosiding Seminar Nasional Pendidikan, Sains dan TeknologiFakultasMatematika dan IlmuPengetahuanAlam Universitas Muhammadiyah Semarang. Retrieved from https://jurnal.unimus.ac.id/index.php/psn120 12010/article/view/3145

25. Suherman, E. 2008. Model Belajar dan PembelajaranBerorientasiKompetensiSiswa. Educare. 5(2): 1-31. Retrieved from http://jurnal.fkip.unla.ac.id/index.php/educa re/article/view/62
26. Susanti, Y. 2018. Hubungan Kemampuanawal dan Kepercayaan DiridenganPrestasiBelajarMatematika pada siswakelas V SDN 4 ResingTahun Pembelajaran 2016/2017. Fondatia: Jurnal Pendidikan Dasar. 2(1): 59-70. Retrieved from https://doi.org/10.36088/fondatia.v2i1.114

27. Umbara, U dan Rahmawati I. 2018. PembelajaranMatematikaBerbantuan

Software Algebratoruntuk Meningkatkan KemampuanPemahamanMatematisSiswa. JurnalElemen. 4(1): 9-19. Retrieved Fromhttps://ejournal.hamzanwadi.ac.id/inde x.php/jel/article/view/508/0

How to cite this article: Aulia Kuntum Arfani, Isti Hidayah, Dwijanto. Mathematics communication skill analysis in means-endanalysis learning assisted with manipulative property (APM) and application based on selfefficacy. International Journal of Research and Review. 2022; 9(1): 151-160. DOI: https://doi. org/10.52403/ijrr.20220120 